\title{
Competitiveness and competitive advantages of chestnut timber laminated products
}

\author{
F. Carbone ${ }^{1}$ (D) S. Moroni ${ }^{1} \cdot$ W. Mattioli ${ }^{1} \cdot$ F. Mazzocchi ${ }^{2} \cdot$ M. Romagnoli $^{1} \cdot$ L. Portoghesi $^{1}$
}

Received: 14 May 2019 / Accepted: 1 April 2020 / Published online: 25 May 2020

(C) INRAE and Springer-Verlag France SAS, part of Springer Nature 2020

\begin{abstract} required. products are more competitive than conventional. beams process has recently developed. non-market characteristics.

- Methods Market space has been defined by determining

- the producer's reserve price limits, using the cost approach criteria;

- the consumer's upper limit, using the market comparison approach;
\end{abstract}

- Key message Chestnut timber is a resource that has so far been underestimated. The production of laminated chestnut beams represents important progress; it is necessary to check its market performances and the opportunities offered from non-market characteristics. To ensure competitiveness margins in the future, dedicated chestnut timber policy is

- Context European Union policies for sustainable development converge towards the enhancement of forest resources. Hypothesis: enlargement of the range of wood products and increase in timber products usage can only be achieved if these

- Aims With respect to conifer timber, chestnut timber has competitive characteristics. However, chestnut timber has had very few opportunities for market development in the last decades. As result of its competitiveness margins, the laminated chestnut

For this product, a conventional market or competitiveness space has been established as well as its extension in relation to

\section{Handling Editor: Barry A. Gardiner}

Contribution of the co-authors

Carbone F. was the scientific responsible of the manuscript and also the coordinator of economic unit. He has developed the elaborations, and he is the author of Sects. 1, 3 and 6. He is the corresponding author.

Moroni Sara has elaborated and submitted market survey, build the economic dataset and elaborated the data; has monitored the chestnut laminated beams process and collected the technical and economic data. Moroni S. in cooperation with Carbone F. are the authors of Sects. 2.2, 4 and 5 .

Romagnoli M. was the scientific manager and project coordinator; she also was the scientific responsible of the monitoring of laminated chestnut beam production process. In cooperation with Mazzocchi F., they have analysed production cycle, machines and technologies used in the laminated chestnut beams production cycle, monitoring the process and elaborate the dataset; they have wrote Sect. 2.1.2.

Portoghesi L. was the scientific manager responsible of the chestnut coppice forest management unit. In cooperation with Mattioli W. they have analysed the chestnut forest management and wrote the section Chestnut forest and log production. They have wrote Sect. 2.1.1.

F. Carbone

fcarbone@unitus.it
Extended author information available on the last page of the article 
- the expansion of the upper limit for the non-market characteristics, the environmentally friendly consumer price, determined through interviews with a sample of responsible consumers.

\section{- Results Limits are:}

- the producer's reserve price is $752.68 € / \mathrm{m}^{3}$;

- the consumer's reserve price is $918.77 € / \mathrm{m}^{3}$;

- in the main regional market (Rome district), the environmentally friendly consumer's price is $1164.08 € / \mathrm{m}^{3}$.

- Conclusion Knowledge of the various market limits of chestnut timber allows producers to assess its competitive margins. Conservation over time of these margins, however, requires dedicated governance, as well as the adoption of a forest strategy aimed at promoting the timber production quality and a marketing plan to promote the knowledge of the characteristics of chestnut wood (market and non-market characteristics) and increase the number of responsible consumers.

Keywords Opportunity cost $\cdot$ Market space $\cdot$ Producer's reserve price $\cdot$ Consumer's reserve price $\cdot$ Environmentally friendly reserve price $\cdot$ Production costs $\cdot$ Market prices

\section{Introduction}

In order to foster sustainable economic development, timber production and other timber products, together with all resources from renewable sources, must be competitive on the market (Forest Europe 2018). The increase in the variety of products that are wood-based and of their market space increases the long-term competitiveness of forestry sector production given that they are a renewable resource and that their products are environmentally friendly.

The Forest Action Plan 2007-2011 (Commission of the European Communities 2006) was the first document that mentioned the competitiveness as one of the main drivers for the forest sector. The necessary financial resources needed to support the plan should be taken from the Rural Development Programme. The subsequent EU Forest Strategy 2013 (European Commission 2013) indicated that competitiveness and the sustainability of the timber transformation production process were both equally important in reaching the goal for an efficient use of resources and energy and in curtailing direct and/or indirect environmental impact. The action plan (European Parliament 2015) highlights the need for innovative products with high added value, which then stand out and transform the abovementioned aims into competitive advantages. The EU forest-based industries' strategy (Commission staff working document 2013) identifies an increase in competitiveness as the means by which to overcome and reverse the forest-based industries' downward trend over the last decade. The same document highlights the need for an increase in consumer demand, obtainable by emphasizing the environmentally friendly performance of wood-based products.

From an economic point of view, competitiveness is the "ability of a firm or a nation to offer products and services that meet local and world markets quality standards, at prices that are competitive and provide adequate returns on the resources employed or consumed in producing them." " Extensive competitiveness analysis has been carried out to investigate the international timber trade (Dieter and Englert 2007; Daigneault et al. 2008), but this can be used for firms and products traded on national or local markets (Chikán 2008). Competitiveness analysis is the tool for validating the market performance of new products once expected technical standards have already been verified.

Ecological, environmental and socio-economic attributes are competitive advantages, which can be applied to timber products in the market (Bliss and Kelly 2008). Main product benefits are (a) the increase in the value of the products; (b) the possibility to attract sensitive and informed consumers (responsible consumers); (c) the introduction of non-market characteristics (competitive advantages) for comparing similar products. Firms that base their market strategy on competitive advantages expect their consumers to pay a premium price for those added benefits.

European chestnut (thereafter, chestnut) is an important species for inland, forest and marginal areas (disadvantages areas) in Italy (Ministry of Agricultural, Food and Forestry Policy, 2008 and 2010; Bounous 2005). Its timber products, of low added value, are sold in local or limited markets. Given its high physical and mechanical standards (Brunetti et al. 2015), the current use is strongly in contrast with EU policies related to the efficient use of resources (European Commission 2011a/a, European Commission 2011b/b) and sustainable bio-economic growth (McCormick and Kautto 2013; European Commission 2012). Moreover, many chestnut operators are requesting policies that would encourage the development of new products (Manetti et al. 2010) with higher added value, which would meet the standards of and have the necessary certification to enter more demanding

\footnotetext{
${ }^{1}$ Business Dictionary, Web Finance. URL download on 13th November 2018.
} 
markets (especially those relating to the use of wood for structural purposes and public procurement markets). The adoption of a strategy to enhance chestnut products responds to the broader need to investigate the socio-economic opportunities arising from smaller markets (Hetemäki and Hurmekoski 2016).

Since the early 1960 s, laminated softwood beams have been exported from Northern and Central Europe to all the other European countries. Their success is due to their ability in overcoming limits imposed by solid wood beams (e.g. size, length, shape etc.), increasing breaking strength because cracks cannot easily propagate and also in guaranteeing laminated products with high standards even for structural use. There is currently evidence that hardwood glulams generally provide a superior physical and mechanical performance (Aicher et al. 2014; Romagnoli et al. 2014), while Brunetti et al. (2015) and Lanvin et al. (2015) have shown that chestnut wood has suitable properties for more complex usages. They have also defined a laminated chestnut beam production process and demonstrated high performance. Laminated chestnut beams (LCBs) are a novelty product in the European market, and they can be an alternative to traditional laminated beams. Moving from the technical to the market aspects, the aims of this study are to verify if LCB products can be competitive on the laminated timber market and the role of their competitive advantages on the market.

The first section of this paper describes the laminated chestnut beam chain and factors that influence competitiveness. The latter section investigates LCBs competitiveness and competitive advantages. The producer and consumer opportunity costs approach has been used to define the market space, while evaluation of comparative advantages has been used to extend the LCBs market space. Relevant suggestions useful for marketing LCBs have been mentioned in the conclusion.

\section{Background}

The chestnut forest area covers 2.5 million hectares (Conedera et al. 2016), less than $2 \%$ of the EU forest area. Compared with the Northern European softwood area and volume (respectively about 100 million hectares and 20 billion cubic meters; Forest Europe 2015), chestnut forest land and timber production is significantly lower. This is a relevant bio-geophysical limit for the chestnut timber market perspectives.

The largest part of chestnut forest area is managed for timber production, and a small area is for fruit production. Chestnut timber production and their wood products have only recently been exposed to a qualification process. European Technical Approval (ETA) for the "Uso Fiume" beams (Brunetti et al. 2013) and machine strength grading implementation (Nocetti et al. 2016; Nocetti et al. 2013a, 2013b; Vega et al. 2012; Nocetti et al. 2010) are both aimed towards obtaining the CE mark (Conformité Européene). The expectation is that new market opportunities should become available.

The study has been developed using the Lazio region case for the following reasons:

a) this region has a forest area of more than 600,000 ha $(30 \%)$. Chestnut forest covers about $6 \%$ of the forest area, the majority of which is managed as coppice for timber production with a high volume for woodwork (used for constructing buildings, or other structural parts of a building or house';

b) many of typical pests and diseases that have affected chestnut plants and other processes that damage timber production are now efficiently contained and mitigated by specific silvicultural approaches (Rigling et al. 2016; Spina and Romagnoli 2010; Vettraino et al. 2005);

c) the chestnut chain is the most relevant socio-economic regional forest chain;

d) Brunetti et al. (2015) developed the LCB experimental process using chestnut timber produced in this region;

e) many monumental buildings in Lazio (and Tuscany) have undergone extraordinary maintenance programmes. Old solid chestnut beams and "Uso fiume" solid beams, used largely in the past for constructing buildings (Manetti et al. 2017), have been replaced by laminated softwood beams.

\subsection{Laminated chestnut beams chain}

The laminated chestnut beam production cycle begins with the forest management of chestnut coppices and ends with the LCB product by chestnut woodworking. It involves logging companies and chestnut sawmills (Fig. 1).

\subsubsection{Chestnut forest and log production}

The Lazio region chestnut forest covers 35,003 ha. Only a few hectares are managed as high forest for fruit production (5895 ha) but the largest forest area is managed as coppices for timber (27,266 ha) (Gasparini and Tabacchi 2011). Overall timber production has been estimated to be $180,000 \mathrm{~m}^{3} /$ year, while chestnut for woodwork is on average $2.09 \mathrm{~m}^{3} / \mathrm{ha} /$ year for a total volume of $56,956 \mathrm{~m}^{3} /$ year (Table 1). Public and private owners are involved in chestnut timber production, and many forest management approaches have been adopted over time (Angelini et al. 2013; Manetti et al. 2002; Amorini et al. 2000). Only a few chestnut firms, usually private chestnut owners, adopt a well-structured forest management approach (Manetti et al. 2017): not less than three intermediate cuttings and a final cutting at about 30 years. Chestnut forest 


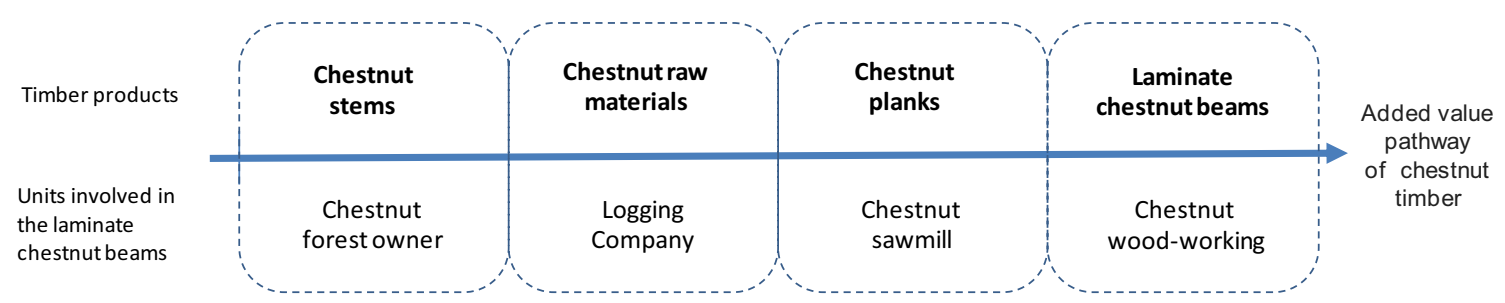

Fig. 1 Laminated chestnut beam chain

owners implement forest management with a logging company that purchases stems already identified to be cut. This organization allows sawmills to buy those timber lots that meet their market needs.

\subsubsection{Laminated chestnut beam production}

Logs are processed in technologically advanced sawmills that have computer numerical control. The first step involves log cross-cutting and selection using a dedicated machine. Two macro-production types are obtained:

- $\quad$ logs used for small poles, scantlings and purlin because they do not have the diameter (average diameter $<15 \mathrm{~cm}$ ) and/or length $(<2 \mathrm{~m})$ suitable for production of boards or beams;

- $\quad$ logs used for higher added value that have standard dimensions (average diameter $>15 \mathrm{~cm}$ and length $>2 \mathrm{~m}$ ) and no defects.

When considering added value production, wood is subject to the following processing:

- $\quad$ squaring of the log (sizing of the two parallel faces) using a band saw with a carriage;
- cutting of logs using a multi-blade saw to obtain the thickness required to produce boards.

Two intermediate product types are obtained:

- chamfer timber such as purlin and "Uso fiume" beams; both have flexible standard dimensions;

- $\quad$ square-edged timber such as different sized boards, rectangular cross section beams and purlin.

Both require further processing. Part of the semi-finished products often undergo further processing in the same sawmill, and wooden trusses, roofing matchboards and indoor or outdoor furniture are produced. Alternatively, semi-finished products are sold on the market as intermediate goods for woodworking processes in order to obtain the highest added value products. Most advanced sawmills are equipped with a kiln designed to artificially dry wood.

First qualification concern selected chestnut boards that have dimensions of length $>2 \mathrm{~m}$; width $>10 \mathrm{~cm}$, thickness $>$ $2 \mathrm{~cm}$, without defects. This material is artificially dried, and they reach the required moisture content of $12 \%$ in 40 days. A second raw qualification is carried out by a sawmill. Any wood with significant defects (large knots, deformation and defective wood etc.) is rejected, while only suitable material of
Table 1 Chestnut woodwork production by region

\begin{tabular}{|c|c|c|c|c|}
\hline \multirow[t]{2}{*}{ Regions } & \multirow{2}{*}{$\begin{array}{l}\text { Chestnut forest area }{ }^{(1)} \\
\text { ha }\end{array}$} & \multicolumn{2}{|c|}{$\begin{array}{l}\text { Chestnut woodwork } \\
\text { production }^{(2)}\end{array}$} & \multirow{2}{*}{$\begin{array}{l}\text { Chestnut woodwork } \\
\text { production per unit of area } \\
\mathrm{m}^{3} / \mathrm{ha}\end{array}$} \\
\hline & & $\mathrm{m}^{3}$ & $\%$ & \\
\hline Campania & 13,509 & 113,782 & 16.63 & 8.42 \\
\hline Calabria & 54,818 & 184,184 & 27.00 & 3.36 \\
\hline Lazio & 27,266 & 56,956 & 8.53 & 2.09 \\
\hline Tuscany & 111,495 & 126,754 & 20.88 & 1.14 \\
\hline Lombardy & 67,885 & 13,882 & 14.88 & 0.20 \\
\hline Piedmont & 143,575 & 40,377 & 11.12 & 0.28 \\
\hline Other regions & 358,159 & 63,169 & 17.60 & 0.18 \\
\hline Total & 605,866 & 485,322 & 100.00 & 0.99 \\
\hline
\end{tabular}

\footnotetext{
${ }^{1}$ Gasparini and Tabacchi 2011

${ }^{2}$ Istituto Nazionale di Statistica, 2003

${ }^{3}$ Our elaboration
} 
a high standard for structural use is delivered to the woodworking company.

A specialized laminated beam woodworking company carries out a third selection on dried chestnut boards. Dried boards are strength graded by a grading machine following the protocol of EN 14081-2 (European standard 2012). Further selection is carried out and defects (such as end shake caused by the drying process or wane that could limit the production of finger joints) are removed using a circular saw. Planks obtained are glued at the head with finger joints to obtain laths with standard lengths; their widths are later reduced to the uniform size by the moulding machine. The next step is to apply the primer, as suggested by the wood adhesive supplier to improve bonding quality, on both sides of the laths, and later glue is applied waiting not less than $15 \mathrm{~min}$. Then, laths and lamellae are glued together in the gluing press. LCBs remain in the glue press for more than $3 \mathrm{~h}$, and later raw LCBs will be reduced to their final uniform size for selling as semi-finished products on the market.

\subsection{Factors influencing competitiveness}

A product is competitive when it meets characteristics suitable for trading and has a price commensurate with that of similar products. Another definition of competitiveness is when goods are not excluded from the market, either by firms producing similar goods or by unexpected market dynamics due to the introduction of alternative products with significantly lower production costs and consequently sensitive lower market price (Begg et al. 2008; Porter 1985).

Competitiveness is the result of exogenous or endogenous decisions, events or dynamics that affect the firm or its products. Exogenous ones are partially, or not at all, controllable. Firms are however called upon to define strategies to counteract the possible reduction of competitiveness or, if external events are positive, to seize the opportunities. In the events of endogenous decisions, the firm has complete control of competitiveness and of its products.

\subsubsection{Institutions}

According to Haider (2012), competitiveness on international markets is determined by three aspects: institutional organization, policies and factors, which influence process productivity.

If they are clearly outlined, these same aspects can be used to analyse competitiveness on national and sub-national markets, assuming all other factors and/or dynamics remain unchanged. It is essential that policies be adopted to safeguard these aspects while defining them in relation to social and economic systems in disadvantaged areas. Furthermore, it is important that certain measures are taken in order to guarantee that products are competitive on the markets, such as ensuring that local natural capital is safeguarded and that resources, products and production processes improve their environmental performances.

Institution organizations, such as national or regional central government, carry out initiatives aimed at ensuring that processes and products conform to established standards in terms of environmental impact and social well-being. Standards that regulate these activities are those in current use. The development of resources and processes is, however, usually carried out through financed policies, which define the aims to which the economic system should aspire and define new markets and new product categories. These policies relate to:

- the area, for which two targets are of particular interest: (a) promotion of historic and cultural values, resources and relevant products with the aim of highlighting the added value deriving from that specific area, when compared with similar competitive products; (b) strengthening infrastructure to ensure efficient, accessible, fast and cheap links between production and commercial sites;

- the sector, specifically forestry chains and forestry ecosystem services, as maintaining these services is important for the area, the environment and the community;

- the firms, by creating conditions whereby production costs are reduced, efficiency is increased, with a positive impact on revenues. The main action lines are (a) bridging the social and economic gap that exists between firms operating in dynamic economic contexts and those operating in disadvantaged areas; (b) modifying the organization and efficiency of production processes (on a social and environmental level), by improving equipment, promoting training etc.; (c) supporting production processes and product research and development; (d) promoting tangible and intangible investments to ecosystem services and preventing disservice, as well as improving the quality of management and use of resources etc.

Any initiative taken to safeguard and promote the above policies will involve all firms, in the area, and will produce positive effects on their competitiveness. Advertising increases competitiveness, whereas in contrast, transaction costs for using natural resources and for developing administrative procedures lead to a loss in competitiveness and, indirectly, favours suppliers of similar and/or alternative products.

\subsubsection{Enterprises}

Having so far considered the feasibility, intrinsic standards and the production process, each firm owes its survival to the production of competitive goods. For any firm, product competitiveness means that (a) the product must be 
appreciated by the market; (b) the market price must cover total production costs; (c) the market price must not become a barrier for consumers; (d) the product should have, at least, one characteristic that makes it preferable when compared with other similar products.

The reduction of costs and the increase in revenue are the main lines of action. These aspects affect:

- the product's market space, its limits being production costs below which the company would operate at a loss (producer's reserve price), and the market price, which, if exceeded, would lead to other products being preferred (consumer's reserve price);

- the widening of the market space as a result of promoting characteristics that are not market-related (environmentally friendly consumer's reserve price) and the recognition of a premium price for performance associated with social, hedonistic, cultural, ecological and environmental characteristics.

\section{Materials and method}

LCBs are competitive in the market if the following conditions are met (Fig. 2):

[Consumer's reserve price $] \geq[$ LCBs market price $] \geq$ [Producer's reserve price $]$.
The producer's and consumer's reserve prices define the market space or competitiveness market space $[\Delta]$. The wider the market space, the greater the product's competitiveness. Formally

$\Delta_{\mathrm{LCBs}}=[$ LCBs Producer's reserve price $]$-[LCBs Consumer's reserve price].

The producer will no longer be competitive on the market if

- LCBs market price < Producer's reserve price because LCBs market price does not cover the total production costs;

- LCBs market price > Consumer's reserve price because consumers can buy similar products that have better performances than LCBs at the same price.

Comparative advantages, however, may lead to an increase in the consumer's threshold. Informed and sensitive consumers (responsible consumers) include these characteristics when evaluating the purchase of market goods. In this way, responsible consumers introduce a new threshold defined as the environmentally friendly consumer reserve price (Fig. 2).

\subsection{Producer's reserve price}

A lower threshold is defined by the total production costs. The cost approach is the most appropriate criterion (Gallerani 2011), using the standard cost procedure. This procedure has

\begin{tabular}{|c|c|c|c|c|c|c|c|}
\hline Market & Conditions & $\begin{array}{l}\text { LCB production } \\
\text { costs }\end{array}$ & $\leq$ & LCB market space & $\leq$ & \multicolumn{2}{|c|}{ Market price of alternative laminated beams } \\
\hline \multirow{5}{*}{ Conventional } & $\begin{array}{l}\text { Characteristics } \\
\text { included }\end{array}$ & \multicolumn{4}{|c|}{ Marketable } & \multirow{2}{*}{\multicolumn{2}{|c|}{ LCBs out of market }} \\
\hline & $\begin{array}{l}\text { Market } \\
\text { evidence }\end{array}$ & $\begin{array}{l}\text { LCBs out of } \\
\text { market }\end{array}$ & \multicolumn{3}{|c|}{ LCBs competitive on the market } & & \\
\hline & Rationality & $\begin{array}{l}\text { Revenue does not } \\
\text { cover production } \\
\text { costs }\end{array}$ & \multicolumn{3}{|c|}{ Revenue covers production costs } & \multicolumn{2}{|c|}{$\begin{array}{l}\text { At same price, there is at least one type of laminate beams } \\
\text { which ensure better performances }\end{array}$} \\
\hline & $\begin{array}{l}\text { Purchase process } \\
\text { approach }\end{array}$ & & \multicolumn{3}{|c|}{ Mono-criteria } & & \\
\hline & Consumer & & \multicolumn{3}{|c|}{ Rational } & & \\
\hline \multirow{5}{*}{$\begin{array}{l}\text { Environmental } \\
\text {-friendly }\end{array}$} & $\begin{array}{l}\text { Characteristics } \\
\text { included }\end{array}$ & & & & & $\begin{array}{l}\text { Conventional and non- } \\
\text { marketable characteristics }\end{array}$ & \\
\hline & $\begin{array}{l}\text { Market } \\
\text { evidence }\end{array}$ & & & & & $\begin{array}{l}\text { Reduction of market weight } \\
\text { and increase of weight of } \\
\text { non-marketable } \\
\text { characteristics }\end{array}$ & \\
\hline & Rationality & & & & & $\begin{array}{l}\text { Non-marketable/market } \\
\text { characteristics these value } \\
\text { are relevantin the market } \\
\text { choice }\end{array}$ & $\begin{array}{c}\text { At same price, there is at } \\
\text { least one type of laminate } \\
\text { beams which ensure better } \\
\text { aggregate performances } \\
\text { (marketable and non- } \\
\text { marketable) }\end{array}$ \\
\hline & $\begin{array}{l}\text { Purchase process } \\
\text { approach }\end{array}$ & & & & & \multicolumn{2}{|c|}{ Multi-criteria } \\
\hline & Consumer & & & & & \multicolumn{2}{|c|}{ Responsible } \\
\hline
\end{tabular}

Fig. 2 Conventional market and environmentally friendly market 
been widely adopted in the industrial sector for prior determination of goods production costs and/or cycles (Bubbio 1994). The most appropriate machinery, tools and manpower, combined with an efficient production cycle organization and technical-economic standards, have been adopted.

Total production costs (TPC) can be split between

- direct costs (DrK) that increase with the quantity produced. They include the main inputs costs and the processing costs;

- indirect costs (IndK), which are those incurred regardless of the quantity produced. These are divided into general costs $(\mathrm{GnK})$ and transaction costs (TrK).

Each cost type has been processed in order to obtain the respective costs per volume of chestnut timber process $\left(€ / \mathrm{m}^{3}\right)$, adopting the discount rate of $2.00 \%$. The life span of infrastructures is 20 years, while for machines, it varies in the range from 5 to 18 years.

The production process under investigation represents the last step of the laminated chestnut beams production chain (Fig. 1). This begins with the purchase of dry chestnut planks from a sawmill and ends with LCBs as final product ready to be sold. Technical parameters are obtained from the monitoring of the LCBs experimental process (Brunetti et al. 2015), while other technical and monetary data was gathered from an interview carried out with the manager of the woodworking firm. Other sources have been market surveys and technical documents.

\subsection{Consumer's reserve price}

The upper threshold is defined by consumer choices. Given that there are budget constraints, rational consumers adopt the market price as the most efficient tool in the purchase process. Formally

$D_{b_{i}}=f\left(B ; P_{i}\right)$

where $\left[D_{b i}\right]$ is the individual demand for the goods $i ;[B]$ is the budget; $\left[P_{i}\right]$ is the market price of product $i$.

The consumer's reserve price has been obtained using a comparative approach developed in the Real Estate Appraisal (Schram 2006) known as Market Comparison Approach (MCA) (Ling and Archer 2010; Rattermann 2007; International Valuation Standard Council 2013). The formal multivariate linear regression model has been implemented as follows:

$Y_{i}=f\left(\beta_{0}+\beta_{1} \cdot X_{1}+\ldots+\beta_{i} x_{i}+\ldots+\beta_{n} \cdot X_{n}+\varepsilon_{i}\right)$

where, $[Y]$ is the vector of market prices (dependent variable); $[X]$ are the vectors of independent variables, $i=1, \ldots . n ;[\beta]$ is the coefficient vector of the independent variables $X, i=$
$1, \ldots \ldots, n ;[\varepsilon]$ is the estimated error of the observation $i$.

The main steps for implementing the MCA have been:

- carrying out a market price survey;

- selecting the elements of comparison;

- preparing a sales summary grid;

- data elaboration;

- results

During the Spring 2014, a market price survey was carried out and 17 timber sellers in the Lazio region have been involved and interviewed. Size classes of timber of $10 \times 10 \mathrm{~cm}$ and $20 \times 20 \mathrm{~cm}$ have been considered, and a total number of 76 laminated beam prices of the main conifer species and beech have been recorded (Carbone et al. 2020). Targets have been the following:

a) the identification of similar market products. The survey shows that coniferous laminated beams are the beams most sold on the regional market. Beams are mainly made from Silver fir (Abies alba Mill.), Norway spruce (Picea abies H.Karst.), European larch (Larix decidua Mill.) and Scots pine (Pinus sylvestris L.). These were often import from Northern Italy and Central Europe (Austria and Germany). Although some market reports mention the presence of poplar (Populous ss.pp.) and beech (Fagus silvatica) laminated beams, our survey did not find any evidence of this in the Lazio Region and in nearby regions;

b) the market price of Silver fir, Norway spruce and European larch laminated beams. The survey indicated that, despite having different technical and mechanical parameters, Silver fir and Norway spruce laminated beams are both included in the GL2 $4^{2}$ class and they have the same market price;

c) other relevant market aspects, such as (i) the price of the laminated beams defined per unit of volume $\left(€ / \mathrm{m}^{3}\right)$ with no difference in the cross-section size classes; (ii) the sale of laminated beams without any species-specific performance certification, reporting only bending strength class parameters of the glued laminated timber, corresponding to GL24 for the entire sample. This variable is not useful for distinguishing different wood products. Therefore, the survey relied on the physical and mechanical parameters of planks, used for producing laminated beams, for the specific species processed in Italy for structural usage (Ente Italiano di Normazione, 2010; Ranta-Maunus et al. 2011; Militz et al. 2003).

\footnotetext{
${ }^{2}$ GL24h: GL $=$ Glued Laminated Timber; 24 = the characteristic bending strength in $\mathrm{MPa} ; \mathrm{h}=$ homogeneous, when lamination that constitutes the laminated beam belongs to the same strength class.
} 
In the beginning, independent variables of the econometric model were:

- durability;

- aesthetic characteristics (wood colour, grain pattern etc.);

- flexural strength;

- density;

- market district.

However, durability, aesthetic characteristics and flexural strength value for defining wood quality have been excluded because they are considered redundant from a statistical point of view, even if chestnut timber provides good performance (Ranta-Maunus et al. 2011). As result, independent variables considered in the model are two: density and market district, although they have been subsequently adjusted to build an econometric model able to determine their marginal contribution to the market price. Specifically, we proceeded as follows:

Density Considering the values given in the literature (Brunetti et al. 2013; Nocetti et al. 2016; Ente Italiano di Normazione, 2010, Ranta-Maunus et al. 2011), for Silver fir and Norway spruce $\left(D_{\mathrm{AA}}=420 \mathrm{Kg} / \mathrm{m}^{3}\right)$, for Scots pine $\left(D_{\mathrm{SP}}=500 \mathrm{Kg} / \mathrm{m}^{3}\right)$ and for European larch $\left(D_{\mathrm{EL}}=610 \mathrm{Kg} /\right.$ $\mathrm{m}^{3}$ ), the model includes two differential variables such as $\Delta_{\mathrm{SP}}$ and $\Delta_{\mathrm{EL}}$, obtained respectively as the difference between the specific density $\Delta_{\mathrm{SP}}$ and $\Delta_{\mathrm{EL}}$ with the density of $\Delta_{\mathrm{AA}}$ assumed as baseline;

Market district (PMK) Indicating where the seller of laminated beams is located, which is represented by one of the five provinces of the Lazio region, that is, Frosinone (FR), Latina (LT), Rieti (RI), Rome (RM) and Viterbo (VT). It is reasonable to assume Rome as the largest market of the region. According to this evidence, laminated beams price in Rome $\left(\mathrm{PMK}_{\mathrm{RM}}\right)$ has been adopted as the baseline for the others district markets $\left(\mathrm{PMK}_{\mathrm{FR}} ; \mathrm{PMK}_{\mathrm{LT}} ; \mathrm{PMK}_{\mathrm{RI}} ; \mathrm{PMK}_{\mathrm{VT}}\right)$. As a result, each province has been considered as a "dummy" variable showing a binary value $(0,1)$ where the value " 1 " is when the seller is located in a specific district while " 0 " otherwise. In this case, the Rome dummy variable has been excluded from the database processed in the econometric model.

\subsection{Competitive advantage characteristics}

The Lancaster theory (Lancaster 1966) states that the consumer seeks to purchase a good not only for its intrinsic characteristics but also in order to use its quality or other characteristics to achieve expected experiences or targets. With regard to the needs that the consumer intends to satisfy by purchasing goods, Lancaster had identified two different types of consumption economy: (a) primitive consumption economy, in which needs are met by the product's functional (or essential) characteristics, typical of a rural economy; (b) sophisticated consumption economy, where needs are also met by qualitative characteristics (social, hedonistic and cultural), typical of an industrial economy. A third category may be added such is the environmentally friendly consumption economy, typical of the green and bio-economy (or of a post-petroleum economy).

The rise of the sophisticated consumption economy, followed by the environmentally friendly consumption economy, has led to the creation of new value profiles for market goods (Fig. 3). At the price commonly associated with the good (e.g. wood), responsible consumers attribute values according to its functions (e.g. carbon dioxide fixation etc.) and services provided (e.g. landscape etc.) that are not commonly considered by the market.

Companies that intend to promote these new value profiles on the market, expect that:

- responsible customers will take other characteristics into account, as well as the listed market price. They would move from evaluating a single criterion when purchasing goods (the price) to considering multi-criteria (evaluating " $n$ " product characteristics);

- environmentally friendly products could command a premium price that responsible consumers would pay even in the case of non-labelled alternative products with a lower price exist on the market.

Affirming that a product is the means of expressing characteristics (topics) to which the consumer gives an order of importance (weight), the individual demand function becomes the following

$D=f\left[B ;\left(P_{i}, \rho_{i}\right),\left(C_{i}, \delta_{i}\right)\right]$

where $[D]$ is the individual request for the product; $[B]$ the budget; $\left[P_{i}\right]$ is the product's price; $\left[\rho_{i}\right]$ is the significance given to the price; $\left[C_{i}\right]$ is the other characteristics of the product " $j$ "; $\left[\delta_{i}\right]$ is the significance of the characteristic " $i$ " of the product.

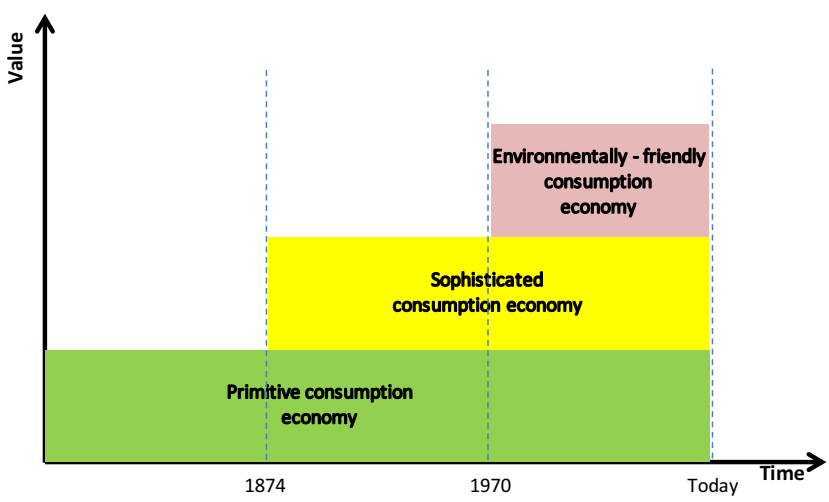

Fig. 3 Product value over time 
Table 2 Evaluation of characteristics defining comparative advantages

\begin{tabular}{|c|c|c|}
\hline $\begin{array}{l}\text { Classification of } \\
\text { characteristics }\end{array}$ & $\begin{array}{l}\text { Characteristics that could prompt } \\
\text { comparative advantages }\end{array}$ & Question \\
\hline Functional & Natural longevity & $\begin{array}{l}\text { Given a scale with " } 10 \text { " as the best longevity performance and "0" as the worst, how would } \\
\text { you evaluate the beams made from the following timber species: Silver fir, Spruce, } \\
\text { Larix, Scots pine and Chestnut? }\end{array}$ \\
\hline \multirow[t]{5}{*}{$\begin{array}{l}\text { Hedonistic } \\
\text { Cultural and } \\
\quad \text { Social }\end{array}$} & Wood grain & $\begin{array}{l}\text { Given a scale with " } 10 \text { " for the best natural grain in laminated beams and "0" as the worst, } \\
\text { how would you evaluate the grain of the following timber species: Silver fir, Spruce, } \\
\text { Larix, Scots pine and chestnut? }\end{array}$ \\
\hline & Safeguarding of local production & $\begin{array}{l}\text { Regardless of the species, given a scale with " } 10 \text { " as the highest score and " } 0 \text { " as the lowest, } \\
\text { what importance do you attribute to the safeguarding of local species in relation to } \\
\text { consolidating a global market? }\end{array}$ \\
\hline & Cultural and environmental familiarity & $\begin{array}{l}\text { Given a scale with " } 10 \text { " as the highest evaluation for cultural and environmental familiarity } \\
\text { with laminated beams, and "0" as the lowest, how would you evaluate the use of } \\
\text { laminated beams of the following species: Silver fir, Spruce, Larix, Scots pine and } \\
\text { Chestnut? }\end{array}$ \\
\hline & $\begin{array}{l}\text { Socio-economic importance of forest } \\
\text { areas }\end{array}$ & $\begin{array}{l}\text { Regardless of the species, given a scale with " } 10 \text { " as the highest score and " } 0 \text { " as the lowest, } \\
\text { how important is it that laminated beams should be produced from timber coming from } \\
\text { forests which have ecological safeguards but in which silviculture for timber production } \\
\text { is permitted? }\end{array}$ \\
\hline & $\begin{array}{l}\text { Sustainable development in inland and } \\
\text { marginal areas }\end{array}$ & $\begin{array}{l}\text { Given a scale with " } 10 \text { " as the best score and " } 0 \text { " as the worst, how important is laminated } \\
\text { beam production from the timber species Silver fir, Spruce, Larix, Scots pine and } \\
\text { Chestnut for inland or marginal areas? }\end{array}$ \\
\hline \multirow[t]{6}{*}{$\begin{array}{l}\text { Ecological and } \\
\text { environmental }\end{array}$} & $\begin{array}{l}\text { Reduction in emissions caused by } \\
\text { transporting laminated beams }\end{array}$ & $\begin{array}{l}\text { Given a scale with " } 10 \text { " as the best score and " } 0 \text { " as the worst, to what extent do laminated } \\
\text { beams produced with timber from Silver fir, Spruce, Larix, Scots pine and Chestnut meet } \\
\text { the aim of reducing the distance between the timber production site, the processing site } \\
\text { and the site of use? }\end{array}$ \\
\hline & Sustainable forest management & $\begin{array}{l}\text { Regardless of the species, given a scale with " } 10 \text { " as the highest importance and " } 0 \text { " as the } \\
\text { least, what score would you give laminated beams made from timber forests managed in } \\
\text { a sustainable manner? }\end{array}$ \\
\hline & Contrasting climate change & $\begin{array}{l}\text { Regardless of the timber species, given a scale with " } 10 \text { " as the highest score and " } 0 \text { " as the } \\
\text { lowest, how important do you consider the use of laminated beams, rather than similar } \\
\text { products whose production processes generate more climate altering emissions? }\end{array}$ \\
\hline & Primary forest protection & $\begin{array}{l}\text { Regardless of the timber species, given a scale with " } 10 \text { " as the highest score and " } 0 \text { " as the } \\
\text { lowest, how important do you consider the use of timber from anthropized forests as a } \\
\text { means of safeguarding primary forests? }\end{array}$ \\
\hline & Post-petroleum economy & $\begin{array}{l}\text { Regardless of the timber species, given a scale with " } 10 \text { " as the highest score and " } 0 \text { " as the } \\
\text { lowest, what score would you assign to the use of laminated beams as a means of } \\
\text { encouraging a bio-based economy? }\end{array}$ \\
\hline & Efficient use of resources & $\begin{array}{l}\text { Regardless of the timber species, given a scale with " } 10 \text { " as the highest score and " } 0 \text { " as the } \\
\text { lowest, how would you evaluate the use of laminated beams as an efficient use of natural } \\
\text { resources? }\end{array}$ \\
\hline
\end{tabular}

Source: our elaboration

The preference of consumers to purchase LCBs is due to a series of characteristics strictly related to the specific product. These were evaluated in a survey (Table 2) developed and given to a group of regional experts. The questions were related to profiles linked to different social, hedonistic, cultural, ecological and environmental characteristics. In order to develop a comparative analysis, the questions were divided as follows:

- those relating to wood characteristics of the various species specifically used for producing laminated beams.
- those related to common characteristics of laminated beams, without any distinction with regard to the species. In this case, the consumer expresses a preference for laminated timber beams over similar products made with other materials.

The following requirements had to be met when identifying any competitive advantages:

- they should not be redundant, that is, the characteristic are already listed on the market; 
- they should enable a comparative analysis of laminated beams produced from different types of timber to be carried out;

- they should permit the rating of laminated beams in relation to important global challenges (climate change, deforestation etc.).

The experts were asked to rate the products

- by behaving as if they were responsible consumers;

- by making use of the metric system defined by the interval between [0] and [10], which are, respectively, the lowest and the highest rating;

- by considering the rating of " 5 " as a sufficient threshold.

The surveys were subsequently elaborated in order to obtain:

- the absolute rating (AR) of each beam;

- the individual preference rating (PR) of each beam involved in the study.

AR index has been obtained as sum of the average values given by single responsible consumers about each wood and its common characteristics. It express the preferability of the consumer to use laminated beam instead of other similar products. AR has been expressed as absolute or relative value. Formally

$\mathrm{AR}=\left[\sum_{j \rightarrow 1}^{12} q_{j}\left(\sum_{i \rightarrow 1}^{5} \mu\left(c_{i, j}\right)\right)\right]_{y}$

where $q$ is the question submitted to the responsible consumer, with $j=1, \ldots, 12$ questions; $c$ is the value expressed from the responsible consumer " $i$ " (from 1 to 20 ), in a scale from " 0 " to "10"; $y$ represents the wood species used for producing the laminated beam (Silver fir; Norway spruce, European larch. Scots pine, Chestnut); AR has been calculated both for all characteristics $(j=1, \ldots, 12)$ subject to evaluation by responsible consumers and, in more detail, also for wood characters $\left(\mathrm{AR}_{\mathrm{wv}} ; j=1, \ldots, 5\right)$ and the common ones $\left(\mathrm{AR}_{\mathrm{Lv}} ; j=6, \ldots, 12\right)$. The last two indexes have been expressed in absolute and relative values, where 250 and 350 points are the maximum scores respectively of the two groups of expressed.

A pairwise comparative analysis has been implemented for calculating the preference rating (PR) of each species using the wood characteristics dataset, given the evidence that common laminated beams characteristics are not species sensitive. The aim is to define the preferability for a laminated beam type of one specific species over the others. Formally, PR absolute value is obtained as

$\left(c_{i, y}-c_{i, y+1}\right)$;
PR relative value is obtained as

$\frac{\left(c_{i, y}-c_{i, y+1}\right)}{\sum_{i \rightarrow 1}^{12} c_{i, y}}$.

\section{Results}

\subsection{Production costs}

The LCB production cycle was monitored for economic analysis. In the total production costs of $752.68 € / \mathrm{m}^{3}$, a distinction is made between direct costs $(84.27 \%)$ that include the cost of inputs $(71.84 \%)$ and processing $(12.44 \%)$, and indirect costs $(15.73 \%)$ of which transaction costs are $6.02 \%$ and general costs $9.71 \%$ (Fig. 4). Details are reported in Table 3. The highest operative cost is the purchase of dry chestnut planks $66.43 \%$, while the cost of glues and pre-gluing products (primer) are $5.51 \%$. Other crucial costs are labour (11.52\%), the entrepreneur's profits $(9.09 \%)$, machinery operating costs, tools and other factors including amortization, maintenance and energy costs, which are $1.55 \%, 0.62 \%$ and $0.91 \%$ respectively. The impact of the other costs is approximately $1 \%$.

The evaluation of an efficient use of resources has been calculated as the ratio between the volume of chestnut timber dispatched $\left(4.67 \mathrm{~m}^{3}\right)$ and the volume made into LCBs $\left(2.46 \mathrm{~m}^{3}\right)$. The LCB production process can be defined as a low efficiency process $(52.74 \%)$, while the amount of timber rejected is $47.26 \%$ of the volume dispatched (Table 4 ), and it is used for energy production.

\subsection{Market price}

Several econometric models have been estimated but only the most statistically significant is reported here. Unfortunately from the market districts, the variable $\left[X_{P M K_{F R}}\right]$ have not statistically significance and it has been out of the econometric model. The list below shows all the variables included in the model with the highest statistical significance:

$$
\begin{aligned}
\mathrm{LBPs}= & \beta_{0}+\left(\beta_{\Delta_{-} \mathrm{SP}} * X_{\Delta_{\mathrm{SP}}}\right)+\left(\beta_{\Delta_{\perp} \mathrm{LX}} * X_{\Delta_{\mathrm{LX}}}\right) \\
& +\left(\beta_{\mathrm{PMK}_{\mathrm{LT}}} * X_{\mathrm{PMK}_{\mathrm{LT}}}\right)+\left(\beta_{\mathrm{PMK}_{\mathrm{RI}}} * X_{\mathrm{PMK}_{\mathrm{RI}}}\right) \\
& +\left(\beta_{\mathrm{PMK}_{\mathrm{VT}}} * X_{\mathrm{PMK}_{\mathrm{VT}}}\right)
\end{aligned}
$$

LBP is the market price of laminated beams (dependent variable); $\beta_{O}$ is the intercept; $\beta_{\Delta_{-} S P}$ is the coefficient of independent variable $\Delta_{\mathrm{SP}} ; \beta_{\Delta}{ }_{L X}$ is the coefficient of independent variables $\Delta_{\mathrm{LX}} ; \Delta_{\mathrm{SP}}$ is the independent variable relative to the greater value of Scots pine density compared with Silver fir and Norway spruce; $\Delta_{\mathrm{LX}}$ is the independent variable relative 
to the greater value of European larch compared with Silver fir and Norway spruce; $\mathrm{PMK}_{\mathrm{LT}}$ is the dummy variable related to the Latina market district; $\mathrm{PMK}_{\mathrm{RI}}$ is the dummy variable related to the Rieti market district; $\mathrm{PMK}_{\mathrm{VT}}$ is the dummy variable related to the Viterbo market district.

Variables included in the econometric model do not show multicollinearity (Table 5). The econometric model obtained has a high statistical significance $\left(R_{\text {adj }}^{2}=0.84\right)$ (Table 6) due to the reduced variability of market prices for each wood species and to the parameterization of the comparison variables. The latter are all highly significant (stud- $t>2$ ). All variables included in the model have performed as expected. Given the incremental approach, the density of chestnut timber coefficient has been obtained through a linear interpolation (Fig. 5). Formally

$\beta_{\Delta_{-} \mathrm{CH}}=\left\{\left[\beta_{\mathrm{SP}}+\frac{\left(\beta_{\Delta_{-} \mathrm{LX}}-\beta_{\Delta_{-} \mathrm{SP}}\right)}{\left(X_{\Delta_{\mathrm{LX}}}-X_{\Delta_{\mathrm{SP}}}\right)}\right] *\left(\Delta_{\mathrm{CH}}-\Delta_{\mathrm{SP}}\right)\right\}=2.42$

The model for estimating the LCBs market price is

$\mathrm{LCB}=\beta_{0}+\left[\beta_{\Delta_{\mathrm{CH}}} *\left(\Delta_{\mathrm{CH}}-\Delta_{\mathrm{AA}}\right)\right]+\mathrm{PMK}_{i}$

where, in addition to the previously described variables, $\Delta_{\mathrm{CH}}$ is the value of chestnut density $\left(580 \mathrm{~kg} / \mathrm{m}^{3}\right)$ and the " $i$ " of the PMK variables is the market district for which the econometric model will be solved. By replacing numbers with letters and given that $\mathrm{PMK}_{\mathrm{RM}}=0$, the result is the following:

$\mathrm{LCB}=531.77+[2.42 *(580-420)]=918.77 € / \mathrm{m}^{3}$.

This upper limit of the reserve price $\left(€ / \mathrm{m}^{3} 918.77\right)$ is related to the Rome market district, which is the main regional market, used as baseline for LCBs in order define the upper limit relative to the other districts. Values of the other market districts are reported in Table 7.

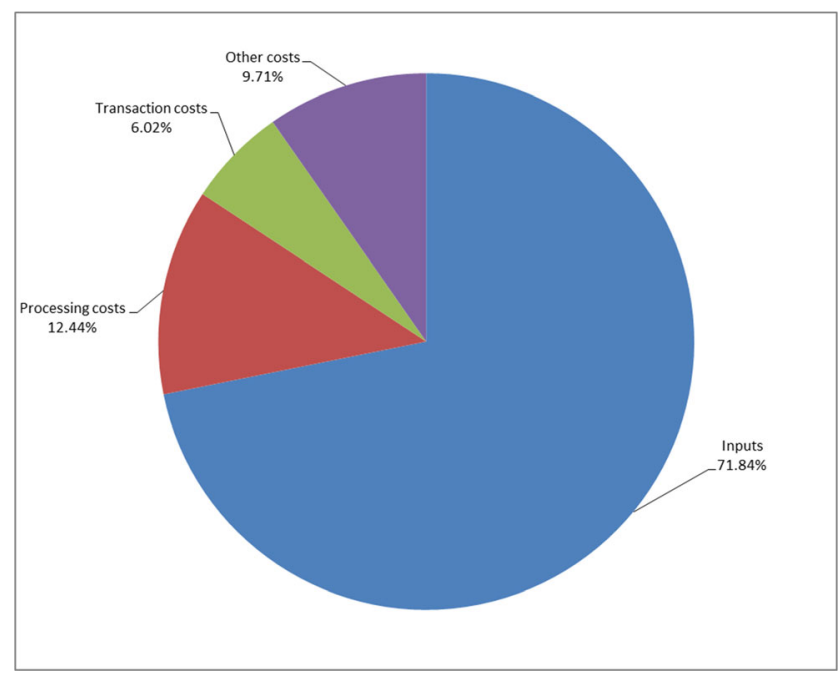

Fig. 4 Laminated chestnut beam production costs
The LCB market space is therefore comprised between the lower limit of $€ / \mathrm{m}^{3} 752.68$ and the upper limit of $€ / \mathrm{m}^{3} 918.77$, while the competitive margin is $€ / \mathrm{m}^{3} 166.09$. However, both upper limit and competitive margin can be modified according to the other market districts.

\subsection{Comparative advantage characteristics}

Twenty responsible consumers took part in the survey and answered to the 12 questions submitted. The highest average value for the AR was awarded to LCBs (72.82), followed by European larch (63.55) and Norway spruce (58.36), while Silver fir and Scots pine registered values that were a bit lower than the other species (Fig. 6). Using the average value of the AR vector as threshold, two sub-vectors have been subsequently obtained, one from AR lower value and the other from AR upper values. The minimum values were generally between 30 and 45, while the maximum values were between 70 and 85.

Five questions dealt specifically with the evaluation of the laminated beams related to the characteristics of specific wood species along with their cultural and environmental role. These questions are considered extremely important in order to define the preferability for laminated beams. European larch laminated beams for example were awarded the highest average values both for the product longevity ( 8.09 points) and their design (6.36 points), whereas preference was given to LCBs for characteristics relating to cultural and environmental familiarity (7.36), for their contribution to the sustainable development of disadvantage areas (9.45 points) and for reducing climate altering gas emissions due to the limited amount of transportation involved ( 6.00 points). AR index shows that chestnut timber has the highest score (34.73) compared with European larch (25.45). Norway spruce has just over 20 score, Silver fir and Scots pine have the lowest score.

The second question group dealt with more common characteristics without any distinction about species. Laminated beams were awarded 6.64 points for safeguarding local production, while 6.09 points were awarded for the social and economic relevance of the territories, both aspects of the social, hedonistic and cultural profile. The highest points scored in the questions relating to ecological and environment aspects were awarded for their function in the indirect protection of primary forests (5.82 points), whereas contrasting climate change and contribution to a post-petroleum economy have the same average score of 5.18. A lower score was awarded for the ability to ensure an efficient use of natural resources.

The PR includes wood characteristics, ranking the species from the highest (Chestnut) to the lowest (Scots pine). Subsequently, the differential per pairs of species in absolute and relative values has been elaborated as reported in Table 8 . The absolute value highlights the gap between species, while the percentage expresses the increase in the market space 


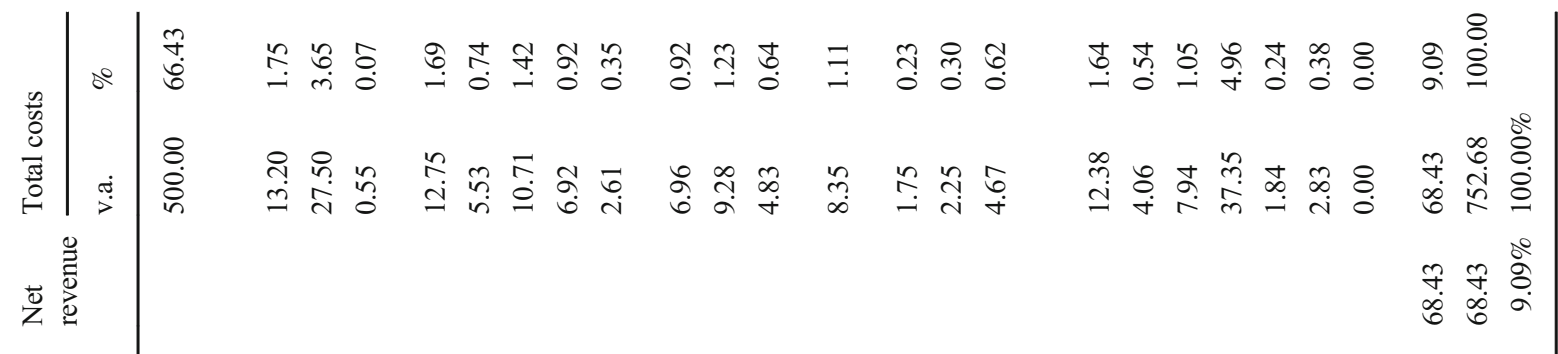

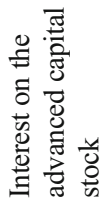

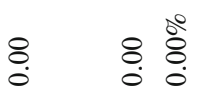
虫
范
总总
产芯芯

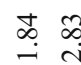

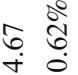
๘
$\stackrel{n}{?}$

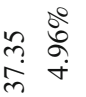
尊总
言哭

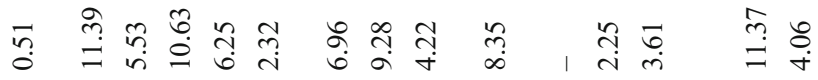
$\stackrel{r}{g}$

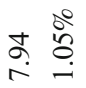

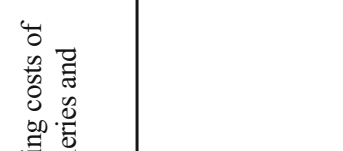

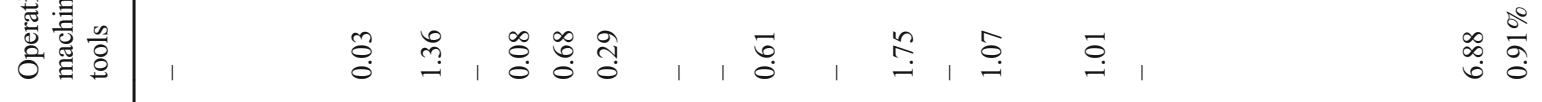

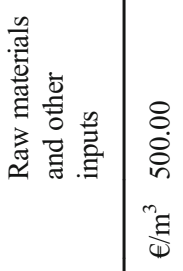

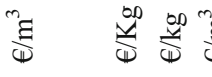
กิ
充
ڤ̊ำ

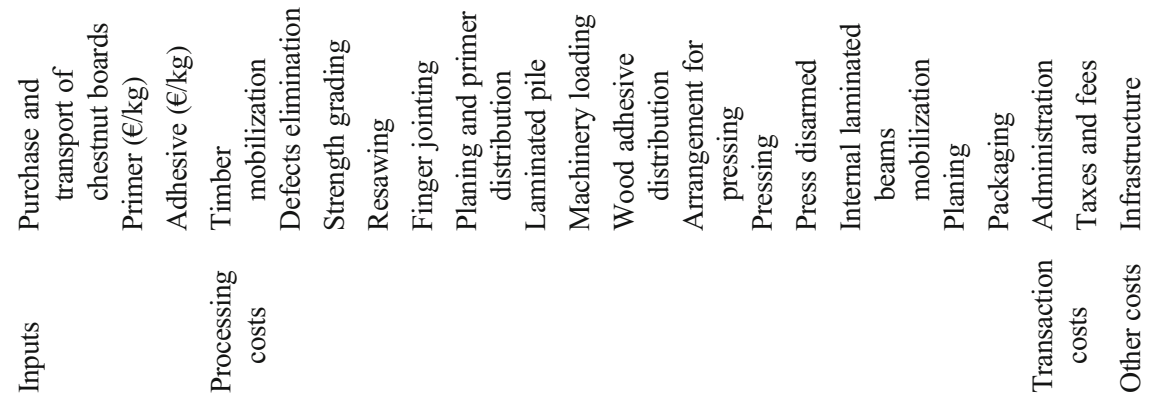
苞哭 
Table 4 Performing line showing the initial and final volumes for each phase

\begin{tabular}{|c|c|c|c|c|c|c|c|}
\hline \multirow[t]{2}{*}{ Actions } & \multirow[t]{2}{*}{ Unit } & \multicolumn{2}{|c|}{ Inputs } & \multicolumn{2}{|c|}{ Outputs } & \multicolumn{2}{|c|}{ Processing losses } \\
\hline & & $n$ & $\begin{array}{l}\text { Volume } \\
\mathrm{m}^{3}\end{array}$ & $n$ & $\begin{array}{l}\text { Volume } \\
\mathrm{m}^{3}\end{array}$ & $\begin{array}{l}\text { Volume } \\
\mathrm{m}^{3}\end{array}$ & $\%$ \\
\hline Timber mobilization $^{1}$ & Packs & 3 & 4.67 & 3 & 4.67 & 2.46 & 47.26 \\
\hline Strength grading & Boards & 372 & 4.67 & 372 & 4.67 & & \\
\hline Defects elimination & Boards & 372 & 4.67 & 366 & 4.59 & & \\
\hline Resawing & Boards & 366 & 4.59 & 1464 & 3.94 & & \\
\hline Finger jointing & Lamellae & 1424 & 3.94 & 1414 & 3.80 & & \\
\hline $\begin{array}{l}\text { Planing and primer } \\
\text { distribution }\end{array}$ & Laths & 278 & 3.33 & 278 & 3.33 & & \\
\hline Laminated pile & Laths & 278 & 3.33 & 278 & 3.33 & & \\
\hline Machinery loading & Laths & 278 & 3.33 & 278 & 3.33 & & \\
\hline Wood adhesive distribution & Laths & 278 & 3.33 & 278 & 3.33 & & \\
\hline Arrangement for pressing & Laths & 278 & 3.33 & 278 & 3.33 & & \\
\hline Pressing & $\begin{array}{l}\text { Laminated } \\
\text { beams }\end{array}$ & 60 & 3.33 & 60 & 3.33 & & \\
\hline Press disarmed & $\begin{array}{l}\text { Laminated } \\
\text { beams }\end{array}$ & 60 & 3.33 & 60 & 3.33 & & \\
\hline Internal laminated beams & $\begin{array}{l}\text { Laminated } \\
\text { beams }\end{array}$ & 60 & 3.33 & 60 & 3.33 & & \\
\hline Planing & $\begin{array}{c}\text { Laminated } \\
\text { beams }\end{array}$ & 60 & 3.33 & 60 & 2.46 & & \\
\hline Packaging & $\begin{array}{l}\text { Laminated } \\
\text { beams }\end{array}$ & 60 & 2.46 & 60 & 2.46 & & \\
\hline
\end{tabular}

${ }^{1}$ Dried plank are transported from the sawmill to the specialized laminated beam woodworking company by truck Source: our elaboration

compared with the upper limit (consumer's reserve price). This value also expresses the enrichment of qualitative characteristics that the minor species should register in order to allow the responsible consumer to prefer these last ones to the superior ones. Higher differentials indicate greater efforts to be made in order to make minor species preferable.

\section{Discussion}

Scientific articles have been written on the LCB production process (Brunetti et al. 2015; Lanvin et al. 2015). Despite being an experimental process, it should, currently, be

Table 5 Results of multicollinearity analysis

\begin{tabular}{lll}
\hline Variables & VIF & Tolerances \\
\hline PMK $_{\mathrm{VT}}$ & 1.4349 & 0.6970 \\
PMK $_{\mathrm{LT}}$ & 1.1806 & 0.8470 \\
$\mathrm{PMK}_{\mathrm{RI}}$ & 1.1281 & 0.8864 \\
$\Delta_{\mathrm{SP}}$ & 1.1472 & 0.8717 \\
$\Delta_{\mathrm{LX}}$ & 1.1607 & 0.8616 \\
\hline
\end{tabular}

Source: our elaboration considered as the most efficient LCBs production process. This production cycle was also monitored for economic analysis.

Total production costs are $752.68 € / \mathrm{m}^{3}$; therefore, firms are competitive if market prices reach this producers' reserve price, whereas lower market prices would not cover production costs. As result, it would be more convenient for a business to abandon this type of production in favour of more traditional products. The present analysis of LCBs production cycle, therefore, highlights the possibility that the total production costs are reduced and the LCBs competitiveness increased. Market price paid per unit of volume of dry plank corresponds to $500 € / \mathrm{m}^{3}$. Two aspects explain such a high price: the high cost of drying planks, which need 40 days compared with the 15 days usually needed for conifers, and the transportation costs, which were high due to the low volumes of products moved from the sawmill to the woodworking enterprise. Moreover, the standard of planks dispatched did not meet the expected standard for LCB production, and, therefore, the efficiency of the process was very low: $47.26 \%$ of the timber dispatched was rejected and used for energy. This was the businesses' and the workers' first experience in producing LCBs, and a series of problems became evident during the process. Improvised solutions were implemented, 
Table 6 Results of the econometric model

\begin{tabular}{|c|c|c|c|c|c|c|c|}
\hline \multirow[t]{5}{*}{ Regression statistic } & \multicolumn{2}{|l|}{ R multiple } & \multicolumn{3}{|l|}{0.9221} & & \\
\hline & \multicolumn{2}{|l|}{ R squared } & \multicolumn{2}{|l|}{0.8502} & & & \\
\hline & \multicolumn{2}{|c|}{$\mathrm{R}$ squared correct } & \multicolumn{2}{|l|}{0.8395} & & & \\
\hline & \multicolumn{2}{|c|}{ Standard error } & \multicolumn{2}{|l|}{83.1764} & & & \\
\hline & \multicolumn{2}{|c|}{ Observations } & 76 & & & & \\
\hline \multirow[t]{4}{*}{ Analysis of variance } & & & gdl & SQ & MQ & $F$ & Statistical significance $F$ \\
\hline & \multicolumn{2}{|l|}{ Regression } & 5 & $2,748,453$ & $549,690.7$ & 79.45444 & $1.804 \mathrm{E}-27$ \\
\hline & \multicolumn{2}{|l|}{ Residual } & 70 & $484,281.9$ & 6918.313 & & \\
\hline & \multicolumn{2}{|l|}{ Total } & 75 & $3,232,735$ & & & \\
\hline \multirow[t]{7}{*}{ Coefficient value and statistic } & Variables & Coefficients & Standard error & Stat $\mathrm{t}$ & Statistical significance & & \\
\hline & Intercepts & 531.77 & 14.59 & 36.46 & 0.00 & & \\
\hline & $\mathrm{PMK}_{\mathrm{VT}}$ & 86.31 & 21.64 & 3.99 & 0.00 & & \\
\hline & $\mathrm{PMK}_{\mathrm{LT}}$ & 99.09 & 44.63 & 2.22 & 0.03 & & \\
\hline & $\mathrm{PMK}_{\mathrm{RI}}$ & 136.53 & 44.03 & 3.10 & 0.00 & & \\
\hline & $\Delta_{\mathrm{SP}}$ & 2.20 & 0.30 & 7.40 & 0.00 & & \\
\hline & $\Delta_{\mathrm{LX}}$ & 2.50 & 0.14 & 17.55 & 0.00 & & \\
\hline
\end{tabular}

Source: our elaboration

and these proved the process to be costly. However, evidences show that, when the LCBs production process is fully operational, it is reasonable to expect an overall improvement in the production cycle and a consequent reduction of the lower market limit.

LCBs resemble coniferous laminated beams due to their physical and mechanical performance. The econometric model estimates an upper reserve price of $918.77 € / \mathrm{m}^{3}$. This value comes from the comparison between the characteristics of LCBs and other comparable laminated products, and this is only related to characteristics listed on the market. LCB properties place them between Silver fir and Norway spruce, the most common laminated coniferous beams on the market, and European larch which has a better laminated beam standard. The research by Brunetti et al. (2015) highlights the fact that chestnut wood's physical and mechanical parameters are significantly higher than those reported in official documents. Therefore, LCBs market price obtained from our elaboration can be considered as being underestimated. The sale of LCBs at a market price superior to the consumer's reserve price would cause consumers to buy laminated beams of other species because they would obtain a better performance at the same price. In the range from 752.68 to 918.77 $€ / \mathrm{m}^{3}$, the common characteristic is $\mathrm{AR}=38.09(54.52 \%)$, which is the preferability of laminated timber beams over the other similar products.

For every price included in the market space, $54.42 \%$ of consumers would buy laminated wooden beams. They would appreciate the characteristics of naturalness, the use of resources harvested from forests already anthropized and at

Fig. 5 Coefficient variation

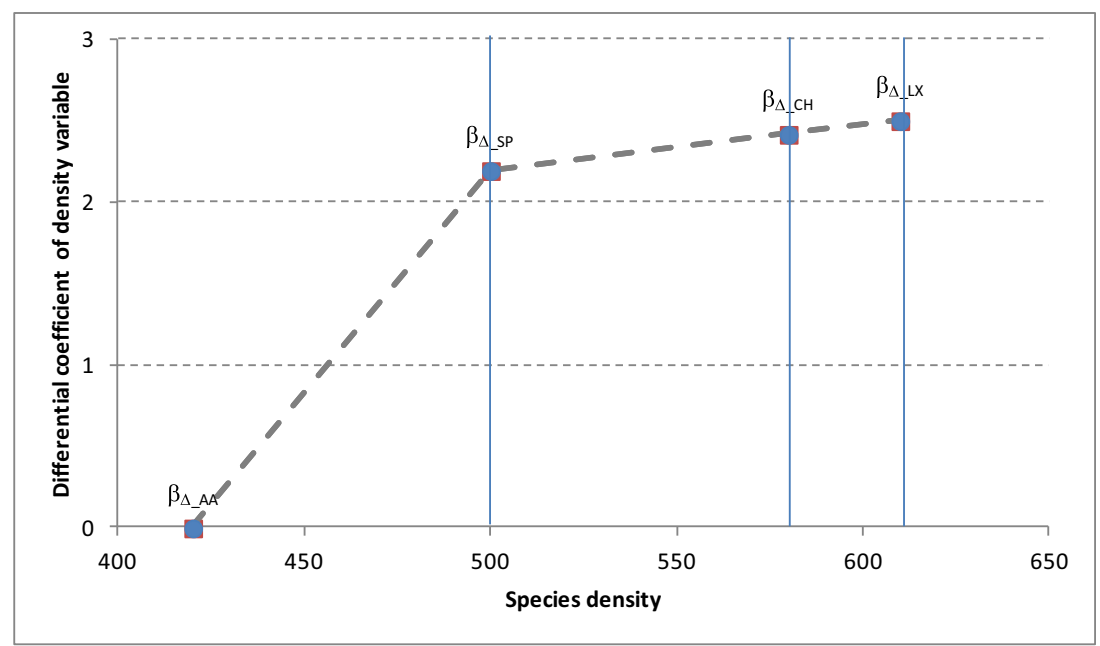


Table 7 Market value of laminated chestnut beams in the Lazio Region

\begin{tabular}{|c|c|c|c|c|c|c|}
\hline \multirow{2}{*}{$\begin{array}{l}\text { Provincial } \\
\text { Market }\end{array}$} & \multirow[t]{2}{*}{ Intercept } & \multicolumn{2}{|c|}{ Market } & \multirow{2}{*}{$\begin{array}{l}\text { Density (Cast)- Density } \\
\left(\mathrm{AB} \_s s p p\right)\end{array}$} & \multirow[t]{2}{*}{ COEFF(cast) } & \multirow{2}{*}{$\begin{array}{l}\begin{array}{l}\text { Market } \\
\text { price }\end{array} \\
€ / \mathrm{m}^{3}\end{array}$} \\
\hline & & Value & Coefficients & & & \\
\hline Rome & 531.77 & 0 & 0 & 160 & 2.42 & 918.77 \\
\hline Viterbo & & 1 & 86.31 & & & 1005.07 \\
\hline Latina & & 1 & 99.09 & & & 1017.86 \\
\hline Rieti & & 1 & 136.53 & & & 1055.30 \\
\hline
\end{tabular}

Source: our elaboration

same time, under sustainable management, the implementation of production processes with low environmental impact, the indirect protection of the primary forests and the support to an economic development based on bio-based resources.

The importance of wood characteristics is not surprising due to the regional nature of the study. The PR index shows the preferability value relative to each species of laminated timber beams. The greater the similarity between characteristics, the lower the PR index. From the market point of view, the greater the PR, the more competitive the product in the market, according to wood characteristics.

Responsible consumers have a marked preference for LCBs: the PR index is 34.73 which is the highest value compared with 19.36 for Scots pine which was the lowest (Fig. 7). Compared with the other laminated beams, LCBs are 9.27 points higher than European larch beams, considered amongst the best beams available on the market and 15.27 higher than Scots pine (Table 9). If these values are expressed in relative terms, this index allows us to quantify the increase in market space registered by LCBs in monetary terms: with respect to European larch beams, it is $+26.70 \%$, equal to $+245.31 € / \mathrm{m}^{3}$ (Table 9). With the consumer's reserve price of $918.77 € / \mathrm{m}^{3}$ as a starting point, the environmentally friendly consumer's reserve price is of $1164.08 € / \mathrm{m}^{3}$ in the main market district of Rome. Operating in a similar manner with respect to laminated beams, the market extension totals approximately $400 € / \mathrm{m}^{3}$ and the relevant values for the environmentally friendly

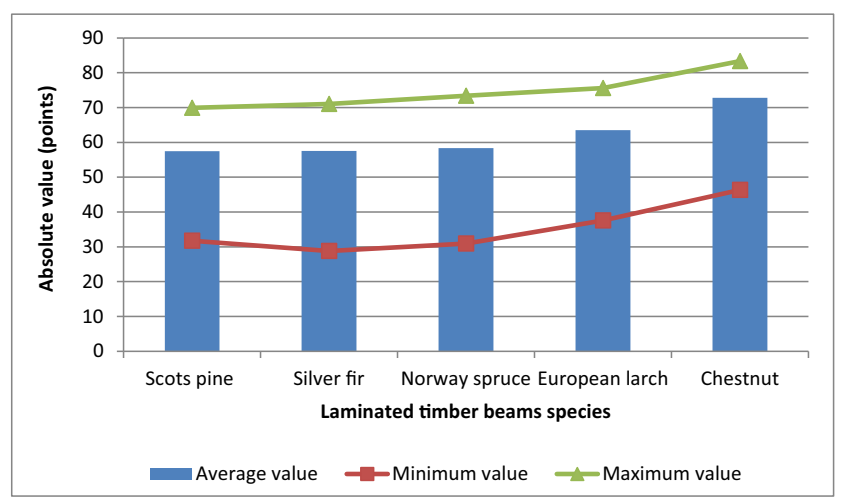

Fig. 6 Absolute rating value results consumer's reserve price exceed $1300 € / \mathrm{m}^{3}$. The highest deviation is for Scots pine, which has an IPR of $44.24 \%$ with the environmentally friendly consumer's reserve price of 1325.21 $€ / \mathrm{m}^{3}$. Responsible consumers, who would always choose to buy laminated chestnut beams due to non-market characteristics, operate within this additional space.

However, firms that produce laminated beams from other species and that wish to improve competitiveness in the LCBs' markets should have a main dedicated market policy that includes two main points:

- a price strategy: reducing the laminated beams price from other species beams, to the point of at which they are lower than the LCBs producer's reserve price;

- a quality strategy: increasing the characteristics not quoted on the market so that responsible customers prefer laminated beams from other species to LCB's.

\section{Conclusions}

In recent years, the forestry sector and the wood processing supply chains have benefitted from particularly favourable European Union policies, and this represents an important opportunity for chestnut wood.

Exploiting the physical mechanical qualities of this wood, in collaboration with the scientific community, should lead to a bridging of the technical, technological and engineering gap. The first example of this are LCBs, which are, from a technical point of view, an alternative to traditional laminated beams and their production is high in added value at an economic level.

The LCBs market space is $166.09 € / \mathrm{m}^{3}$ with a flexibility of $22.07 \%$. The producer's reserve price $\left(752.68 € / \mathrm{m}^{3}\right)$ is affected by the experimental nature of the production process, the negative aspects of which are the lack of efficiency in the production process, the absence of economy scale, low productivity and the high incidence of certain costs (sawn timber and transport costs) and the large of quantity of wood rejected. Nevertheless, in a well-articulated and well-consolidated production cycle, the aspects above should decrease, while 
Table 8 Points and score of laminate beams characteristics

\begin{tabular}{|c|c|c|c|c|c|c|c|}
\hline \multirow[t]{2}{*}{ Characteristics } & & & \multicolumn{5}{|c|}{ Wood species of laminate beams } \\
\hline & & & $\begin{array}{l}\text { Silver } \\
\text { fir }\end{array}$ & Spruce & Larix & $\begin{array}{l}\text { Scots } \\
\text { pine }\end{array}$ & Chestnut \\
\hline \multirow[t]{7}{*}{ Wood characteristics } & 1 & Natural longevity & 3.00 & 4.82 & 8.09 & 5.73 & 6.64 \\
\hline & 2 & Wood grain & 4.45 & 5.64 & 6.36 & 3.27 & 5.27 \\
\hline & 3 & Cultural and environmental familiarity & 4.64 & 3.64 & 4.55 & 4.00 & 7.36 \\
\hline & 4 & Sustainable development of disadvantage areas & 1.73 & 2.09 & 2.18 & 2.27 & 9.45 \\
\hline & 5 & $\begin{array}{l}\text { Reduction in emissions caused by transporting } \\
\text { laminated beams }\end{array}$ & 5.64 & 4.09 & 4.27 & 4.09 & 6.00 \\
\hline & \multirow{2}{*}{$\begin{array}{l}\text { Total } \\
\qquad \mathrm{AR}_{w W c c}\end{array}$} & Absolute values & 19.45 & 20.27 & 25.45 & 19.36 & 34.73 \\
\hline & & Relative values & $38.91 \%$ & $40.55 \%$ & $50.91 \%$ & $38.73 \%$ & $69.45 \%$ \\
\hline \multirow{9}{*}{$\begin{array}{l}\text { Laminate beams common } \\
\text { characteristics }\end{array}$} & 6 & Safeguarding local production & 6.64 & 6.64 & 6.64 & 6.64 & 6.64 \\
\hline & 7 & Socio-economic importance of forest area & 6.09 & 6.09 & 6.09 & 6.09 & 6.09 \\
\hline & 8 & Sustainable forest management & 5.00 & 5.00 & 5.00 & 5.00 & 5.00 \\
\hline & 9 & Contrasting climate change & 5.18 & 5.18 & 5.18 & 5.18 & 5.18 \\
\hline & 10 & Primary forest protection & 5.82 & 5.82 & 5.82 & 5.82 & 5.82 \\
\hline & 11 & Post-petroleum economy & 5.18 & 5.18 & 5.18 & 5.18 & 5.18 \\
\hline & 12 & Efficient use of natural resources & 4.18 & 4.18 & 4.18 & 4.18 & 4.18 \\
\hline & Total $\mathrm{AR}_{\mathrm{Lc}}$ & Absolute values & 38.09 & & & & \\
\hline & & Relative values & $54.42 \%$ & & & & \\
\hline \multicolumn{3}{|c|}{ Total score of laminate beams characteristics } & 57.55 & 58.36 & 63.55 & 57.45 & 72.82 \\
\hline
\end{tabular}

Source: our elaboration

positive effects should be registered in terms of production costs. The measures adopted from the national and regional government in order to support the economy in mountain areas can also reduce production, mobilization and transaction costs with positive effects in competitiveness.

In the main regional market, the consumer's reserve price is $918.77 € / \mathrm{m}^{3}$, whereas in the other districts, the upper limits are higher. This increment can be explained by the lower sizes and volume of laminated beams traded in the markets and the higher mobilization costs. However, Brunetti et al. (2015) highlighted that chestnut wood has higher standards, which could increase if forest management was well structured, became more regular, was aimed at quality production and

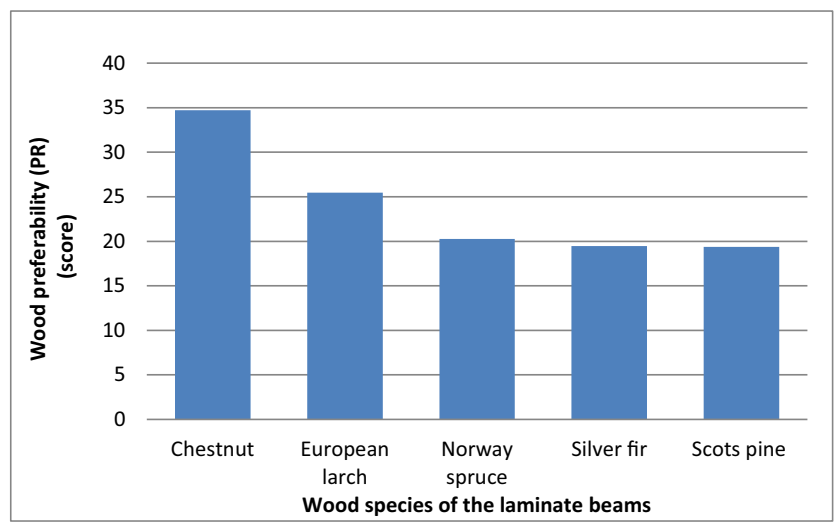

Fig. 7 Specific character value for timber speci adopted automated qualification of wood. These initiatives would have positive effects and increase the threshold of the consumer's reserve price in all market districts.

LCBs are strongly preferred at regional level, and the PR confirms this preference. Their market space widens from + $245.31 € / \mathrm{m}^{3}$ with respect to European larch and reaches the maximum value of $+406.44 € / \mathrm{m}^{3}$ with respect to Scots pine laminated beams. Responsible consumers operate in this market space, and choosing LCBs by virtue of their characteristics, which are not market-orientated but rather their choice, is the result of a multi-criteria assessment of social, hedonistic, cultural, ecological and environmental characteristics. The latter evidence indicates that the areas where there is familiarity with chestnut are the main LCB markets. Nevertheless, responsible consumers could decide to choose beams from other species in the case the LCBs price exceeds the environmentally friendly consumer's reserve price or laminated beams from other species improve their wood characteristics or the price of these beams and LCBs were the same.

The market opportunities of LCBs are contrasted by important limits, and these limits should be taken into account in dedicated policies. The main issues are:

- Chestnut timber is the output of forest ecosystem service that requires rational management in order to ensure continuity of production and the belonging ecosystem; 
Table 9 Results of comparative pairwise analysis of laminated beams species

\begin{tabular}{|c|c|c|c|c|c|c|c|c|c|c|}
\hline \multirow[t]{2}{*}{ Wood species } & \multicolumn{2}{|c|}{ Chestnut } & \multicolumn{2}{|c|}{ Larix } & \multicolumn{2}{|c|}{ Spruce } & \multicolumn{2}{|c|}{ Silver fir } & \multicolumn{2}{|c|}{ Scots pine } \\
\hline & a.v. & $\Delta \%$ & a.v. & $\Delta \%$ & a.v. & $\Delta \%$ & a.v. & $\Delta \%$ & a.v. & $\Delta \%$ \\
\hline Chestnut & 0.00 & 0.00 & & & & & & & & \\
\hline Larix & 9.27 & 26.70 & 0.00 & 0.00 & & & & & & \\
\hline Spruce & 14.45 & 41.62 & 5.18 & 20.36 & 0.00 & 0.00 & & & & \\
\hline Silver fir & 15.36 & 43.98 & 6.00 & 23.58 & 0.82 & 4.04 & 0.00 & 0.00 & & \\
\hline Scots pine & 15.27 & 44.24 & 6.09 & 23.93 & 0.91 & 4.48 & 0.47 & $0.47 \%$ & 0.00 & 0.00 \\
\hline
\end{tabular}

Source: our elaboration

- Overall, the production capacity of chestnut woods is rather small. A global economy of this product is not a winning strategy because conifer and European larch laminated beams are more competitive, have a longer market tradition and the product is very well known in the market; moreover, LCB advantages at the local scale becomes a disadvantage in a globalized market.

- The chestnut timber sector currently does not have a public governance with the involvement of all stakeholder. On the contrary, each single operator interacts individually with national or regional government institutions. This reduce dramatically the opportunity to obtain measures coherent with the socio-economic relevance of chestnut economy in the mountain areas.

The last point concerns the market demand. A dedicated chestnut wood policy should produce a social marketing plan in order to enlarge the number of responsible consumers, spread the knowledge about chestnut wood characteristics and consequently promote all timber chestnut products, including the LCBs.

Acknowledgements The project involved forest owners, logging companies, and a laminated beam company, while the scientific partners were the University of Tuscia and the National Research Council (CNRIVALSA). Prof.ssa Romagnoli M. was the manager and scientific coordinator of the project. The authors thank all those who cooperate on the project and whose contribution made the development of this manuscript possible.

Data availability statement The datasets generated and/or analysed during the current study are available in the Zenodo repository, https://doi. org/10.5281/zenodo. 3727823

Funding information The research is supported by the project "Processes and products innovation of the chestnut chain of custody for structural use and improvement of mechanical resistant classes of solid wood" developed by the Lazio Region with the Rural Development Plan 2007-2013 in the Measure n. 124 - Cooperation.

Compliance with ethical standards The authors declare that they obtained the informed consent from all participants involved in this study.
Conflict of interest The authors declare that they have no conflict of interest.

\section{References}

Aicher S, Christian Z, Dill-Langer G (2014) Hardwood glulams - emerging timber products of superior mechanical properties. World Conference of Timber Engineering. Proceeding. pp. 287-296

Amorini E, Bruschini S, Manetti MC (2000) Alternative silvicultural systems in chestnut coppice: effects of silvicultural practices on stand structure and tree growth. Ecol Mediterr 26:155-162

Angelini A, Mattioli W, Merlini P, Corona P, Portoghesi L (2013) Empirical modelling of chestnut coppice yield for Cimini and Vicani mountains (Central Italy). Ann Silvic Res 37:7-12

Begg D, Fischer S, Dornbusch R (2008) Economics, 9th edn. McGrawHill, New York

Bliss JC, Kelly EC (2008) Comparative advantages of small-scale forestry among emerging Forest tenures. Small Scale For 7:95-104. https://doi.org/10.1007/s11842-008-9043-5

Bounous G (2005) The chestnut: a multipurpose resource for the new millennium. Acta Hortic 693:33-40. https://doi.org/10.17660/ ActaHortic.2005.693.1

Brunetti M, Nocetti M, Burato P (2013) Strength properties of chestnut structural timber with wane. Adv Mater Res 778:377-384. https:// doi.org/10.4028/www.scientific.net/AMR.778.377

Brunetti M, Silvestri A, Nocetti M, Burato P, Moroni S, Carbone F, Portoghesi L, Romagnoli M (2015) Travi lamellari in castagno. Sherwood 215:9-14

Bubbio A (1994). Analisi dei costi e gestione d'impresa. Guerini Scientifica: 364

Carbone F, Moroni S, Mattioli W, Mazzocchi F, Romagnoli M, Portoghesi L (2020) Dataset of a regional market survey about laminated timber beams. V2. Zenodo. [Dataset]. https://doi.org/10. 5281/zenodo.3727823

Chikán A (2008) "National and firm competitiveness: a general research model". Competitiveness review. Int Bus J 18:20-28. https://doi. org/10.1108/10595420810874583

Commission of the European Communities (2006) EU Forest Action Plan. Communication from the Commission to the Council and the European Parliament. COM (2006) 302 final. Brussels, 15.6.2006

Commission staff working document (2013) A blueprint for the EU forest-based industries (woodworking, furniture, pulp \& paper manufacturing and converting, printing). SWD(2013) 343 final. Brussels, 20.9.2013

Conedera M, Tinner W, Krebs P, de Rigo D, Caudullo G (2016) Castanea sativa in Europe: distribution, habitat, usage and threats. In: SanMiguel-Ayanz J, de Rigo D, Caudullo G, Houston Durrant T, 
Mauri (eds) European Atlas of Forest Tree Specie. Publ. Off. EU, Luxembourg, pp 78-79

Daigneault AJ, Sohngen B, Sedjo R (2008) Exchange rates and the competitiveness of the United States timber sector in a global economy. For Policy Econ 10:108-116

Dieter M, Englert H (2007) Competitiveness in the global forest industry sector: an empirical study with special emphasis on Germany. Eur J For Res 126:401-412. https://doi.org/10.1007/s10342-006-0159-x

European Standard (2012) EN 14081-2. Timber structures - Strength graded structural timber with rectangular cross section - Part 2: Machine grading; additional requirements for initial type testing. Brussels

Ente Italiano di Normazione (UNI) (2010) UNI 11035. Legno strutturale - Classificazione a vista di legnami secondo la resistenza meccanica. Parte 1-2-3, Roma

European Commission (2013) A new EU Forest Strategy: for forests and the forest-based sector. Communication from the Commission to the European Parliament, the Council, the European Economic and Social Committee and the Committee of the Regions. $\operatorname{COM(2013)} 659$ final. Brussels, 20.9.2013

European Commission (2011a/a) A resource-efficient Europe - Flagship initiative under the Europe 2020 Strategy. Communication from the Commission to the European Parliament, the Council, the European Economic and Social Committee and the Committee of the Regions. European Commission. COM(2011) 21 final. Brussels, 26.1.2011

European Commission, (2011b/b) Roadmap to a Resource Efficient Europe. Communication from the Commission to the European Parliament, the Council, the Economic and Social Committee and the Committee of the Regions. $\operatorname{COM(2011)~} 571$ final. Brussels, 20.9.2011

European Commission (2012) Innovating for Sustainable Growth: A Bio economy for Europe. Communication from the commission to the European Parliament, the Council, the European Economic and Social Committee and the Committee of the Regions. COM(2012) 60 final. Brussels, 13.2.2012

European Parliament (2015) A new EU Forest Strategy: for forests and the forest-based sector' (2014/2223(INI). Texts adopted on 28 April 2015. Strasburg

Forest Europe (2015) State of Europe's forests 2015. In: Ministerial Conference on the Protection of Forests in Europe. Liaison Unit, Madrid

Forest Europe (2018) Enhancing the Long-term Competitiveness of the Forest Sector in a Green Economy: Policies for Forest-Based Bioeconomy in Europe. Workshop Report. 29 May 2018, Brussels

Gallerani V (2011). Manuale di Estimo. McGraw-Hill, $2^{\circ}$ Edition, pp.: 379

Gasparini P, Tabacchi G. (eds), (2011) L'inventario nazionale delle Foreste e dei serbatoi di carbonio. INFC-2005. Secondo inventario forestale nazionale, metodi e risultati. Edagricole Bologna

Haider JI (2012) Impact of business regulatory reforms on economic growth. J Jpn Int Econ Elsevier 26:285-307

Hetemäki L, Hurmekoski E (2016) Forest products markets under change: review and research implications. Curr For Rep 2:177188. https://doi.org/10.1007/s40725-016-0042-z

International Valuation Standard Council (2013) International Valuation Standard 2013. Framework and requirement. London, London

Istituto Nazionale di Statistica (ISTAT) (2003) Coltivazioni agricole, foreste e caccia. Coll. Informazioni, n. 28. Roma

Lancaster KJ (1966) A new approach to consumer theory. J Polit Econ $74: 132-157$

Lanvin JD, Legrand G, Simon F, Faye C, Prince C, Lemaire J (2015) Strength assessment and potential for use as glulam of French chestnut lumber. In: Proceeding. $5^{\text {th }}$ International Scientific Conference on Hardwood Processing and International Academy of wood Science - Annual Meeting, pp 131-138
Ling D, Archer W (2010) Real estate principle: a value approach. McGraw-Hill

Manetti MC, Amorini E, Cutini A (2002) Alternative silvicultural options for chestnut coppice stands: evaluation of the sustainability by silvicultural and ecological indicators. Research Reports, Forestry and Wood Science and Technology, 67: 77-96

Manetti MC, Becagli C, Carbone F, Corona P, Giannini T, Pelleri F, Romano R (2017). Linee guida per la selvicoltura dei cedui di castagno. Rete Rurale Nazionale, Consiglio per la ricerca in Agricoltura e l'analisi dell'economia agraria. Roma

Manetti MC, Amorini E, Becagli C, Pelleri F, Pividori M, Schleppi P, Zingg A, Conedera M (2010) Quality wood production from chestnut (Castanea sativa Mill.) coppice forests - comparison between different silvicultural approaches. Acta Hortic 866:683-692. https:// doi.org/10.17660/ActaHortic.2010.866.91

McCormick K, Kautto N (2013) The bioeconomy in Europe: an overview. Sustainability 5:2589-2608. https://doi.org/10.3390/ su5062589

Militz H, Busetto D, Hapla F (2003) Investigation on natural durability and sorption properties of Italian chestnut (Castanea sativa Mill.) from coppice stands. Eur J Wood Wood Prod 61:133. https://doi. org/10.1007/s00107-002-0357-2

Ministery of Agricultural, Food and Forestry Policy (2008) Framework program for forest sector. In: Ministero delle Politiche Agricole. Roma, Alimentari e Forestali

Ministery of Agricultural, Food and Forestry Policy (2010) National chestnut plan 2010/2013. Ministero delle Politiche Agricole, Alimentari e Forestali, Roma

Nocetti M, Bacher M, Berti S, Brunetti M, Burato P (2013a) Machine grading of chestnut structural timber with wane. Proceedings of the 4rd International Scientific Conference on Hardwood Processing (ISCHP2013), October 7-9, Firenze, Italy: 185-192

Nocetti M, Bacher M, Brunetti M, Crivellaro A, van de Kuilen JW (2010) Machine grading of Italian structural timber: preliminary results on different wood specie. In: Proceedings of the "World Conference on Timber Engineering", June 20-24. Riva del Garda, Trento

Nocetti M, Brancheriau L, Bacher M, Brunetti M, Crivellaro A (2013b) Relationship between local and global modulus of elasticity in bending and its consequence on structural timber. Eur J Wood Wood Prod 7:297-308. https://doi.org/10.1007/s00107-013-0682-7.IF1. 105

Nocetti M, Brunetti M, Bacher M (2016) Efficiency of the machine grading of chestnut structural timber: prediction of strength classes by dry and wet measurements. Mater Struct 49:4439-4450. https://doi. org/10.1617/s11527-016-0799-3

Porter ME (1985) Competitive advantage: creating and sustaining superior performace. The Free Press, New York

Ranta-Maunus A, Denzler JK, Stapel P (2011) Strength of European timber. Part 2. Properties of spruce and pine tested in Gradewood project. VTT Technical Research Centre of Finland

Rattermann M.R. 2007. Valuation by comparison. Residential Analysis and Logic. Appraisal Institute. Chicago

Rigling D, Schütz-Bryner S, Heiniger U, Prospero S (2016). Cancro corticale del castagno. Sintomatologia, biologia e misure di lotta. Notizie per la pratica. Instituto Federale di Ricerca WSL 54: 8 p

Romagnoli M, Cavalli D, Spina S (2014) Wood quality of chestnut: relationships between ring width, specific gravity and physical and mechanical properties. Bioresources 9:1132-1147

Schram JF (2006) Real Estate Appraisal. Rockwell Publishing, Bellevue

Spina S, Romagnoli M (2010) Characterization of ring shake defect in chestnut (Castanea sativa Mill.) wood in the Lazio Region (Italy). Forestry 83:315-327. https://doi.org/10.1093/forestry/cpq014

Vega A, Dieste A, Guaita M, Majada J, Baño V (2012) Modelling of the mechanical properties of Castanea sativa Mill. Structural timber by a combination of non-destructive variables and visual grading 
parameters. Eur J Wood Wood Prod 70:839-844. https://doi.org/10. 1007/s00107-012-0626-7

Vettraino AM, Morel O, Perlerou C, Robin C, Diamandis S, Vannini A (2005) Occurrence and distribution of Phytophthora species in European chestnut stands, and their association with Ink Disease and crown decline. Eur J Plant Pathol 111:169-180
Publisher's note Springer Nature remains neutral with regard to jurisdictional claims in published maps and institutional affiliations.

\section{Affiliations}

\section{F. Carbone ${ }^{1}$ (i) $\cdot$ S. Moroni ${ }^{1} \cdot$ W. Mattioli ${ }^{1} \cdot$ F. Mazzocchi $^{2} \cdot$ M. Romagnoli $^{1} \cdot$ L. Portoghesi $^{1}$}

S. Moroni
saramoroni7@gmail.com

W. Mattioli

walter.mattioli@unitus.it

F. Mazzocchi

mazzocchi.francesco@yahoo.it

1 Department for Innovation in Biological, Agro-food and Forest systems - DIBAF, University of Tuscia, Via San Camillo de Lellis, snc, 01100 Viterbo, Italy
M. Romagnoli mroma@unitus.it

L. Portoghesi

lporto@unitus.it

2 Department of Agriculture and Forest Sciences - DAFNE, University of Tuscia, Via San Camillo de Lellis, snc, 01100 Viterbo, Italy 